\title{
Amino Acids Identification of Over Fermented Tempeh, The Hydrolysate and The Seasoning Product Hydrolysed by Calotropin from Crown Flower (Calotropis gigantea)
}

\author{
Yuli Witono $^{\# 1}$, Simon Bambang Widjanarko ${ }^{*}$, Mujianto ${ }^{2}$, Dessy Tri Rachmawati* \\ \# Department of Agricultural Product Technology, Faculty of Agricultural Technology, University of Jember, Indonesia \\ E-mail: ${ }^{1}$ yuliwitono.ftp@unej.ac.id \\ * Department of Agricultural Product Technology, Faculty of Agricultural Technology, Brawijaya University, Indonesia \\ ${ }^{2}$ Department of Agricultural Industrial Technology, Faculty of Engineering, Wijaya Kusuma University, Surabaya, Indonesia
}

\begin{abstract}
The aims of this study was to investigate the amino acid (AAs) composition of over fermented tempeh (OFT), the hydrolysates and the seasoning product that hydrolyzed by calotropin from Calotropis gigantea. OFT was hydrolyzed by $0.15 \%$ calotropin at $55^{\circ} \mathrm{C}$ for 3 hours. The hydrolysates was mixed with $13.3 \%$ glucose; $13.3 \%$ salt; and $13.3 \%$ of caramelized sugar, and then boiled for $10 \mathrm{~min}$ to make the seasoning. AAs compositions of OFT, the hydrolysates of OFT (HOFT), and the seasoning product of OFT (SOFT) were identified by HPLC. Seventeen AAs have identified and computed. HOFT contained the highest AAs 377.71 $\mathrm{mg} / 100 \mathrm{~g}$, followed by OFT $136.14 \mathrm{mg} / 100 \mathrm{~g}$ and SOFT $60.22 \mathrm{mg} / 100 \mathrm{~g}$. The highest amount of AAs in all samples was glutamic acid. These results indicate that the hydrolysis of OFT by calotropin increase the AAs compounds and can be applied as seasoning.
\end{abstract}

Keywords — amino acid, over fermented tempeh, hydrolysates, seasoning, calotropin from Calotropis gigantea.

\section{INTRODUCTION}

Tempeh originates from Central and East Java Indonesia and gains interest as a major protein source aside from meat. Yellow-seeded soya beans are the most common and preferred raw materials for tempeh, but others substrate such barley [1], ground bean cowpea [2], and oats [3] also have been reported to be suitable in tempe production. The main process to make tempeh is boiling, de-hulling, soaking and incubation. The micro flora in tempe fermentation is complex, as tempeh is a result of mixed cultures such as moulds, yeast, lactic acid bacteria and various other bacteria. The most important genus is Rhizopus species such as $R$. microspores, $R$. oligosporus, and R. oryzae [4].

Tempeh made from soybeans is rich in not only soy protein, glycosidized isoflavones, and vitamin $\mathrm{B}$, all which were originally present in soy bean, but also free amino acids and isoflavone-aglycones that are produced during the fermentation process [5]. The mould, Rhizopus sp. produced a variety of carbohydrates, lipases, and proteases, which degrade macronutrients into substances of lower mass, with higher water-solubility. Vitamins, phytochemicals and anti- oxidative constituents are also formed [4]. Due to its high anti-oxidative activity [6], antibacterial activity [7,8] and the decreasing effects of plasma low-density lipoprotein (LDL) levels [4], tempeh intake has been reported to decrease the effects of chronic degenerative diseases, including cancer, coronary diseases, osteoporosis, and menopausal symptoms.

Simple technique handling of tempeh caused the short shelf life, so unsold tempeh is perishable. Tempeh that was not immediately consumed more than 2 days called over fermented tempe (OFT) and the amount reach 4-5\% from the total production [9]. An approach to improve the functional properties of OFT is enzymatic treatments. Pepsin, papain or trypsin had been shown to enhance the solubility and emulsifying properties of soybean protein isolates [10]. Soy protein hydrolysates were a potential substitution for MSG (Monosodium Glutamate) as food seasoning [11]. Through hydrolysis technique, proteins can be converted into amino acids compound, nucleotides, and a wide variety of peptides. The materials used to form the umami taste in foods are often called flavor enhancers or seasoning.

Calotropin from Calotropis gigantea is one kind of the indigenous proteolytic enzymes from Indonesia. This 
calotopin is the classic exopeptidase [12] which is very suitable for many applications in manufacture of protein hydrolysates. The aims of this study were to identify the amino acids compound of OFT, the hydrolysates of OFT (HOFT), and the seasoning product of FT (SOFT).

\section{MATERIALS AND METHODS}

\section{A. Materials}

OFT in the study purchased from Tanjung market, Jember Indonesia with Sumber Mas label. OFT was 2 days over fermented in the room temperature. Chemical materials used specification pro analysis Merck brands (Germany) covering $0.1 \mathrm{~N} \mathrm{NaOH}, 1 \mathrm{~N}$ and $0.5 \mathrm{~N} \mathrm{HCl}, 70 \%$ acetone, $0.1 \mathrm{M}$ and 0.05 phosphate buffer $\mathrm{pH} 7$, n-hexane, acetonitrile, lowry reagent, follin, 50\% methanol, and Na-acetate, and tri-ethylamine.

\section{B. Preparation of Samples}

OFT was steamed at $100^{\circ} \mathrm{C}$ for $10 \mathrm{~min}$ to stop the fermentation process and mashed by blender. After that OFT was hydrolyzed by $0.15 \%$ calotropin at $55^{\circ} \mathrm{C}$ for 3 hours to produce the hydrolysates (HOFT), then boiled at $100^{\circ} \mathrm{C}$ for 15 min to inactivated enzyme. After that be centrifuged on $3000 \mathrm{rpm}$ at room temperature for $10 \mathrm{~min}$, and taken the supernatant. The hydrolysates mixed with $13.3 \%$ glucose; $13.3 \%$ salt; and $13.3 \%$ of caramelized sugar, and then boiled for $10 \mathrm{~min}$ to produce the seasoning (SOFT).

\section{Chemical Properties Analysis}

The determinations of the soluble proteins [13], maillard [14] and colour [15] of OFT were carried out at the Chemistry and Bio Chemistry of Agricultural product Laboratory, Department of Agricultural Product Technology, University of Jember, Indonesia.

All samples of this study were processed immediately for amino acids analysis at Indonesian Center of Post-Harvest Research Laboratory, Bogor Agricultural University, Indonesia. Freeze-dried samples were analysed after acid hydrolysis in $6 \mathrm{~N} \mathrm{HCl}$ for $22 \mathrm{~h}$ at $110^{\circ} \mathrm{C}$ in glass tubes under nitrogen. Hydrolysis was accelerated by heating. Sample was filtered, and then added with drying solution (methanol, natrium acetate, triethylamine). Derivatization reagent (methanol, picoiotrocianat / PITC, triethilamine) were added, incubated for $20 \mathrm{~min}$ and then mixed with natrium acetate buffer. Samples were injected in HPLC device (analytical column Pico tag 3,9 x $150 \mathrm{~nm}$; mobile phase acetonitril $60 \%$ and buffer natrium acetate $1 \mathrm{M}$, detector UV; wave length $254 \mathrm{~nm}$ at the room temperature).

Aflatoxin analysis for SOFT has done at Indonesian Center For Post-Harvest Research Laboratory, Bogor Agricultural University, Indonesia. Sample added by methanol $\mathrm{NaOH}(\mathrm{MeOH})$ and incubated in water-bath at $80^{\circ} \mathrm{C}$ for $30 \mathrm{~min}$, chilled. Added by buffer phosphate saline and n-hexane, homogenous and then filtered. Filtrate was injected in HPLC device (column C18; mobile phase water : methanol : acetonitrile/ 50:40:10; detector flourecent; wave length $465 \mathrm{~nm}$ at the room temperature).

\section{Data Analysis}

The data of the result was analysed descriptively. To interprete easily, the data were ploted in the table, or a figure.

\section{RESULT AND DISCUSSION}

\section{A. Soluble Protein, Maillard and Colour of HOFT (Hydrolysates of Over Fermented Tempeh)}

The data of soluble protein, maillard and color can be seen in Table 1.

TABLE I

SOLUBLE PROTEIN, MAILLARD, AND COLOR

\begin{tabular}{|l|c|c|}
\hline \multicolumn{1}{|c|}{ Parameters } & HOFT & $\begin{array}{c}\text { Soy bean } \\
\text { hydrolysates }\end{array}{ }^{[16]}$ \\
\hline Soluble protein (\%) & $6.58 \pm 0.12$ & 6.16 \\
\hline Maillard & $0.43 \pm 0.05$ & 0.35 \\
\hline Colour & $76.50 \pm 0.93$ & 87.35 \\
L $^{*}$ & $5.65 \pm 0.19$ & 7.23 \\
$\mathrm{a}^{*}$ & $25.76 \pm 0.13$ & 10.14 \\
$\mathrm{~b}^{*}$ & *The average value + STDEV \\
The
\end{tabular}

Table 1 shows HOFT contains of soluble proteins $(6.58 \pm$ $0.12 \%)$ which is higher than soybean hydrolysates $(6.16 \%)$ (Table 1). During the fermentation of soya beans in tempe production, several biochemical changes take place which degrade the macronutrients into substances of lower molecular mass, with higher water solubility [4]. Whereas the change in nitrogen content during fermentation is negligible, an increase of free amino acids takes place, due to hydrolysis proteins [17]. The degree of hydrolysis strongly depends on fungal strain and the fermentation conditions.

Maillard product of HOFT $(0.43 \pm 0.05)$ was also higher than soybean hydrolysates $(0.35)$ (Table 1$)$. Higher soluble proteins will increase the maillard product [18], and higher maillard product will decrease the brightness of product. The colour of HOFT is darker than soy bean hydrolysates because of the higher maillard product.

\section{B. Amino Acid Composition}

The samples of this study are OFT, HOFT, and SOFT. They belong non-economically of the OFT depending upon consumer's preference in Indonesia. Seventeen amino acids (AAs) were identified and computed their percentages for each samples (Table 2). The HOFT contain the highest of total AAs $377.71 \mathrm{mg} / 100 \mathrm{~g}$, followed by OFT 136.14 $\mathrm{mg} / 100 \mathrm{~g}$ and SOFT $60.22 \mathrm{mg} / 100 \mathrm{~g}$. The highest kind of AAs in OFT, HOFT and SOFT is glutamic acid which amounts are $13.87 \% ; 14.78 \%$ and $18.96 \%$ respectively.

Amino acids (AAs) were the major elements that had been used in assessing the nutritional value of the OFT study. AAs results varied between the studies of OFT, HOFT and SOFT. The variety in total AAs indicates that enzymatic activity by calotropin from Calotropis gigantea increased the AAs total. This is because of calotropin break down proteins into short peptides and amino acids. According to Nielsen [19], the greater concentration of proteases that more peptide bonds of proteins are broken into simple peptides caused increasing the number of amino acid and also increasing protein solubility. One part of calotropin from Calotropis gigantea hydrolysed 842.1846 parts of dry soy beans compounds with velocity reaction of $1 / 2 V_{\max }$ [12]. 
TABLE II

AMINO ACID COMPOSITION OF OFT, HOFT, AND SOFT

\begin{tabular}{|l|c|c|c|c|c|c|}
\hline Amino Acids & $\begin{array}{c}\text { OFT } \\
(\mathrm{mg} / \\
100 \mathrm{~g})\end{array}$ & $\begin{array}{c}\% \\
\text { from } \\
\text { total } \\
\text { AAs }\end{array}$ & $\begin{array}{c}\text { HOFT } \\
(\mathrm{mg} / \\
100 \mathrm{~g})\end{array}$ & $\begin{array}{c}\% \\
\text { from } \\
\text { total } \\
\text { AAs }\end{array}$ & $\begin{array}{c}\text { SOFT } \\
(\mathrm{mg} / \\
100 \mathrm{~g})\end{array}$ & $\begin{array}{c}\% \\
\text { from } \\
\text { total } \\
\text { AAs }\end{array}$ \\
\hline Aspartic & 15.79 & 11.60 & 49.52 & 13.11 & 7.53 & 12.50 \\
\hline Glutamic & 18.88 & 13.87 & 55.84 & 14.78 & 11.42 & 18.96 \\
\hline Serine & 8.08 & 5.94 & 22.85 & 6.05 & 3.77 & 6.26 \\
\hline Glycine & 3.37 & 2.47 & 7.51 & 1.99 & 1.02 & 1.69 \\
\hline Histidine & 4.94 & 3.63 & 7.75 & 2.05 & 1.93 & 3.21 \\
\hline Arginine & 8.74 & 6.42 & 15.60 & 4.13 & 4.34 & 7.21 \\
\hline Threonine & 4.11 & 3.02 & 11.76 & 3.11 & 1.74 & 2.89 \\
\hline Alanine & 6.76 & 4.96 & 25.35 & 6.71 & 2.16 & 3.58 \\
\hline Proline & 7.61 & 5.59 & 13.29 & 3.52 & 4.18 & 6.94 \\
\hline Tirosin & 5.22 & 3.83 & 13.25 & 3.51 & 2.06 & 3.42 \\
\hline Valine & 9.86 & 7.25 & 23.47 & 6.21 & 1.78 & 2.96 \\
\hline Methionine & 5.48 & 4.03 & 37.95 & 10.05 & 2.11 & 3.50 \\
\hline Cystine & 2.73 & 2.01 & 6.82 & 1.80 & 1.40 & 2.32 \\
\hline Isoleucine & 5.11 & 3.75 & 15.34 & 4.06 & 3.23 & 5.36 \\
\hline Leucine & 16.23 & 11.92 & 35.87 & 9.50 & 4.86 & 8.06 \\
\hline Phenylalanine & 3.89 & 2.86 & 12.97 & 3.43 & 1.48 & 2.46 \\
\hline Lysine & 9.34 & 6.86 & 22.58 & 5.98 & 5.22 & 8.67 \\
\hline Total & 136.14 & 100.00 & 377.71 & 100.00 & 60.22 & 100.00 \\
\hline
\end{tabular}

\section{Essential Amino Acids}

Seven essential amino acids (EAAs) were identified among the total of amino acids of all the study (Figure 1). HOFT contain the highest percentage of EAAs $40.96 \%$; followed by OFT $40.46 \%$; and the SOFT $34.65 \%$. Results of EAAs showed that HOFT can be used as EAAs resources and also potential to be applied as seasoning.

EAAs contents in seasoning product will make savory taste. Savory taste that is formed from short-chain peptides, amino acids and flavor of the resulting maillard product provide preferred flavor composition. However, combination of high protease concentrations and hydrolysis time will generate hydrolysates taste less favored. As stated by Nielsen [19], when the degree of hydrolysis reached the condition in which the hydrophobic peptide group to be exposed will lead to a bitter taste.

\section{Aflatoxin of SOFT (The Seasoning of Fermented Tempe)}

Aflatoxins are naturally occurring mycotoxins that are produced by Aspergillus flavus and Aspergillus parasiticus, species of fungi [20]. Human are exposed to aflatoxins by consuming foods contaminated with product or fungal growth. The symptoms of aflatoxins contamination are vomiting, abdominal pain, pulmonary edema, convulsions, coma, and death with cerebral edema, fatty involvement of the liver, kidneys, and heart. Especially aflatoxins B1 are potential carcinogens in human and animals [21].

The United States Food and Drug Administration (FDA) has established action levels for aflatoxin present in food or feed to protect human and animal health which range between $20-300 \mathrm{pbb}$ [22]. Utami (2008) showed that OFT from Sumber mas label contained AFB1 $0.8 \mathrm{ppb}$, lower than FDA level [23]. The results of this research showed that SOFT contain AFB1 $0.156 \pm 0.04 \mathrm{ppb}$ which is lower than FDA levels and did not contain AFB2, AFG1 and AFG2. Its indicated that SOFT also safe to be consumed.

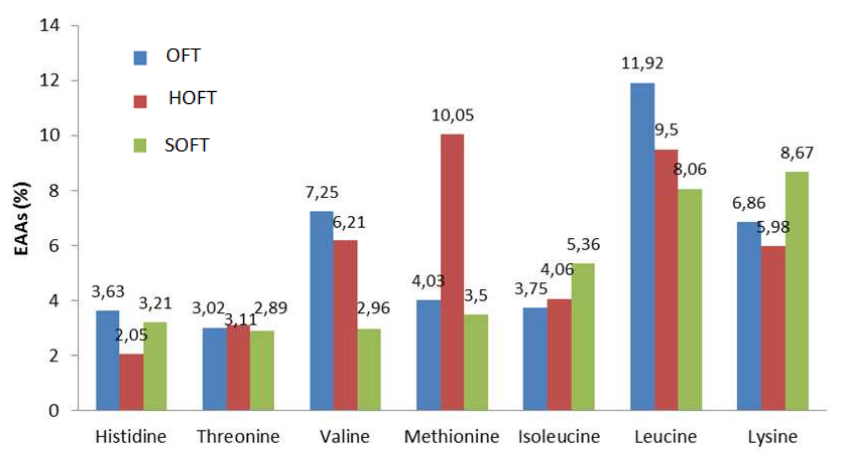

Figure 1. Essential Amino Acids Contents of Over Fermented Tempeh (OFT), Hydrolyzed of OFT (HOFT), and Seasoning of OFT (SOFT)

\section{E. Potential application of HFT in the Seasoning Product}

Flavourzyme are protease/peptidase that has been used to produce a protein hydrolysate with acceptable functional properties. The characteristics of hydrolysates directly affect the functional properties and the uses as food ingredients [24]. Functionality of food protein has been defined as any physicochemical property which affects the processing and behavior of protein in food system as judged by the quality attributes of the final product [25].

Glutamic acid, a key compound in cellular metabolism, taste, and neurotransmission, is a salt of the non-essential amino acid [26]. Among food ingredients, glutamate is present in both its free amino acid form (glutamic acid form) and in its bound form as glutamate within dietary proteins; however, when bound to proteins, glutamate is tasteless and does not elicit the umami response. The taste sensation of umami requires protein hydrolysis which renders free glutamic acid [27]. The high glutamic acid and AAs contents of HOFT indicated that HOFT have potential to be applied as seasoning product substituted MSG (Monosodium glutamate). HOFT will be more safe and healthy to be consumed than MSG.

\section{CONCLUSIONS}

The hydrolysis of OFT by calotropin from Calotropis gigantea increased the AAs compounds, and the hydrolysate was able to be used as seasoning product.

\section{ACKNOWLEDGMENT}

We would like to thanks to the Research and Community Service of Directorate General of High Education for financially supporting this research through Competitive Research Grant Program of Budget Year 2012.

\section{REFERENCES}

[1] Feng, X.M., Larsen, T.O., \& Schnürer, J. (2007). Production of volatile compounds by Rhizopus oligosporus during soybean and barley tempeh fermentation. International Journal of Food Microbiology 113, pp. 133-141.

[2] Egounlety, M. (2001). Sensory evaluation and nutritive value of tempe snacks in West Africa. International Journal of Food Properties 4, pp. 513-522.

[3] Eklund-Jonsson, C., Sandberg, A., \& Alminger, M.L. (2006) Reduction of phytate content while preserving minerals during whole grain cereal tempe fermentation. Jounal of Cereal Science 44, pp. 154-460. 
[4] Nout, M.J.R., Kiers, J.L. (2005). Tempe fermentation, innovation and functionality: update into the third millenium. Journal of Applied Microbiology 98, pp. 789-805.

[5] Karyadi, D., \& Lukito, W. (1996). Beneficial effects of tempe in disease prevention and treatement. Nutr. Rev., 54, S94-98.

[6] Watanabe, N.; Fujimoto, K. \& Aoki, H. (2007). Antioxidant activities of the water-soluble fraction in tempeh-like fermented soybean (GABA-tempeh). Int. J. Food Sci. Nutr., 58, 577-587.

[7] Kiers, J.L., Nout, M.J.R., Rombouts, F.M., Nabuurs, M.J.A., Van der Meulen, J. (2002). Inhibition of adhesion of enterotoxic Escherichia coli K88 by soya bean tempe. Letters in applied microbiology 35, pp. 311-315.

[8] Kobayasi, S.Y., Okazaki, N., \& Koseki, T. (1992). Purification and characterization of an antibiotic substance produced from Rhizopus oligosporus IFO 8631. Bioscience, Biotechnology and Biochemistry 56, pp. 94-98.

[9] Pratomo A. (2000). Utilization of Lactobacillus plantarum and rice flour in an effort to inhibit damage to soybean tempe. Thesis Postgraduated. Brawijaya University, Indonesia, p 1-2.

[10] Kim, S.Y., Park, P.S.W., \& Rhee, K.C. (1990). Functional properties of proteolytic enzyme modified soy protein isolate. J. Agric. Food Chem, 38(3): 651-656.

[11] Indriasari, L. (2006). Beware of Other Chemicals in Food. Kompas, Jakarta-Indonesia.

[12] Witono, Y., \& W.W. Kang. (2010). Specific Characteristic of Novel Cystein Protease From Indonesian 'Biduri' Plant (Calotropis gigantea). Proceeding of The Korea Food Conference and Symposium, Incheon Korea 17-18 June 2010.

[13] Walker, J.M. (2002). The Protein Protocols Handbook. Second Edition. Humana Press, New Jersey, 3-10.

[14] Hofmann, T., Bors, W., \& Stettmaier, K. (1999). Studies on Radical Intermidiates in the Early Stage of the Non-enzymatic Browning Reaction of Carbohydrates and Amino Acids. J. Agric. Food Chem, 47: 379-390.

[15] Hutching, J.B. (1994). Food Colour and Apperance. Glasgow: Blackie Academic and Professional.
[16] Witono. (2008). Ekstraksi dan Karakterisasi Enzim Protease dari Tanaman Biduri (Calotropis gigantea). Thesis. Brawijaya University. Malang.

[17] De Reu, J.C., ten Wolde, R.C., de Groot, J., Nout, M.J.R., Rombouts, F.M., \& Gruppen, H. (1995). Protein hydrolysis during soybean tempe fermentation with Rhizopus oligosporus. Journal of Agricultural and Food Chemistry 43, pp. 2235-2239.

[18] Subagio, A., Hartanti, S., Windrati, W.S., Unus, Fauzi, M., and Herry, B. (2002). Characteristics of protein hydrolysate from tempe. Jurnal Teknologi \& Industri Pangan, 8: 204-210.

[19] Nielsen, P.M. (1997). Food proteins and their application. Marcel Dekker, Inc. New York.

[20] Wannop, C.C. (1961). Histopathology of Turkey X disease in Great Britain Avian Disease 5 (4): 371 -381. Doi:10.2307/1587768.JSTOR 1587768.

[21] Eaton, D.L., \& Groopman, J.D. (1994). The Toxicology of Aflatoxins. Academic press, New York, pp $383-426$.

[22] FDA. (2013). Guidance for Industry: Action Levels for Poisonous or Deleterious Substances in Human Food and Animal Fee. August 2000 [Retrieved march 10, 2013].

[23] Utami, N.N. 2008. Karakteristik Kimiawi dan Kandungan Aflatoksin Tempe Segar dan Tempe Afkir Selama Penyimpanan (Studi Kasus di Pasar Tanjung, Jember). Skripsi. Fakultas Teknologi Pertanian. Universitas Brawijaya. Malang

[24] Kristinsson, H.G., \& Rasco, B.A. (2000). Fish protein hydrolysates: production, biochemical, and functional properties. Critical review of Food Science and Nutrition, 40:43-81.

[25] Kinsella, J.E. (1976). Functional properties of protein in foods: a survey. Critical Reviews of Food Science and Nutrition, 8 (4): 219.

[26] Kondoh, T., Mallick, H., \& Torii, K. (2009). Activation of the gutbrain axis by dietary glutamate and physiologic significance in energy homeostatis. Am J Clin Nutr. 90:832S-837S.

[27] Populin, T., Moret, S., Truant, S., \& Conte, L.( 2007). A survey on the presence of free glutamic acid in food stuffs, with and without added monosodium glutamate. Food Chem, 2007;104:1712-1717. 